\title{
PERANCANGAN GAMBAR RUMAH PANGGUNG PADA TUKANG KAYU KELURAHAN WOLOAN DUA KECAMATAN TOMOHON BARAT KOTA TOMOHON
}

\author{
Fransiscus L. P. J. Lumape, \& Morris, S. S. S. Tumanduk \\ Jurusan Pendidikan Teknnik Bangunan, Fakultas Teknik, \\ Universitas Negeri Manado \\ lumapejani11@gmail.com; morristumanduk@gmail.com
}

\begin{abstract}
Abstrak
Pemahaman Tukang Kayu pada umumnya dalam merancang gambar, baik gambar rumah panggung tidak memahami asas ilmiah dalam analisis dan desain perancangan, hal ini diperlukan pengajaran pendidikan formal dalam rekayasa perancangan gambar rumah. Salah satu bentuk solusi untuk mengatasi masalah tersebut diatas, adalah kegiatan penerapan teknologi rumah panggung dengan memberikan pelatihan teknik perancangan gambar rumah panggung yang diberikan kepada para tukang kayu di Kelurahan Woloan Dua, Kecamatan Tomohon Barat, Kota Tomohon. Pembahasan materi pelatihan oleh tim pengabdi menyepakati bahwa pada hari pertama dilakukan pelatihan dengan metode ceramah dan menggunakan media berupa makalah. Ada 2 (Dua) materi yang disampaikan kepada peserta pelatihan yaitu: Prinsip Perencanaan Rumah Panggung, dan Aspek Perencanaan dan Perancangn Rumah Panggung. Penyampaian materi dilakukan oleh tim PKM Unima dibantu Lurah dan Pegawai Kelurahan Woloan Dua. Pada hari kedua dilakukan pelatihan dengan metode demonstrasi dengan media berupa cara menggambar dengan cepat memakai program Autocat dan dilanjutkan oleh peserta pelatihan di bawah petunjuk narasumber. Hasil pelaksanaan kegiatan pengabdian dapat disimpulkan bahwa: (1) kegiatan pengabdian dapat meningkatkan pengetahuan tentang teknik perancangan gambar rumah panggung, dan (2) untuk lebih meningkatkan pengetahuan cara mengatasi permasalahan dalam teknik perancangan gambar rumah panggung. Kegiatan pengabdian secara keseluruhan dapat dinilai baik dilihat dari 4 (empat) komponen, yaitu: keberhasilan target jumlah peserta pelatihan (100\%), ketercapaian tujuan pelatihan (80\%), ketercapaian target materi yang telah direncanakan (80\%), dan kemampuan peserta dalam penguasaan materi (70\%).
\end{abstract}

Kata Kunci: Pelatihan, teori teknik perancangan gambar rumah panggung, tukang kayu di Kelurahan Woloan Dua.

\section{PENDAHULUAN}

Pemahaman Tukang Kayu pada umumnya dalam merancang gambar, baik gambar rumah panggung tidak memahami asas ilmiah dalam analisis dan desain perancangan, hal ini diperlukan pengajaran pendidikan formal dalam rekayasa perancangan gambar rumah. Pekerja pembangunan rumah panggung di Kelurahan Woloan Dua, setiap tahun mengalami peningkatan jumlah yang signifikan. Peningkatan ini dikarenakan jumlah pengangguran pada usia produktif adalah pemuda putus sekolah, tetapi peningkatan jumlah tersebut tidak dibarengi dengan ketrampilan yang memadai. Keterampilan kerja sebagai tukang yang mereka miliki masih bersifat otodidak (belajar sendiri) dan bersifat turun temurun, hal ini kurang bisa menjamin mutu hasil pekerjaan suatu bangunan, baik bangunan Kayu maupun bangunan kayu. Adapun ketrampilan yang mereka miliki, rata-rata masih bersifat 
relatif tradisional (pola yang sudah lama) dan belum mengikuti pola dan bentuk sekarang ini. Kekurangan lain juga diakibatkan bahwa masih sangat jarang para pemuda putus sekolah tersebut mendapat pelatihan tentang berbagai ketrampilan hidup, termasuk didalamnya mereka tidak dapat mengakses informasi tentang perkembangan teknologi, khusunya teknologi pertukangan.

Universitas Negeri Manado melalui Lembaga Pengabdian Kepada Masyarakat (LPM), merupakan suatu lembaga yang dapat memfasilitasi beberapa kegiatan sebagai upaya untuk mengatasi permasalahan dimasyarakat, seperti pemberian program ketrampilan kecakapan hidup (life skills). Program seperti life skills tersebut menjadi hal penting dan relevan untuk dilakukan di Kelurahan Woloan Dua, sebagai upaya memberi ketrampilan yang lebih modern khususnya pada teknologi rumah panggung, dan sebagai upaya mengurangi pengangguran. Kegiatan ini juga diharapkan dapat meningkatkan pendapatan ekonomi keluarga dan masyarakat di Kelurahan Woloan Dua.

Salah satu bentuk solusi untuk mengatasi masalah tersebut diatas, adalah kegiatan penerapan teknologi rumah panggung dengan memberikan pelatihan teknik perancangan gambar rumah panggung yang diberikan kepada para tukang kayu di Kelurahan Woloan Dua, Kecamatan Tomohon Barat, Kota Tomohon. Manfaat pelatihan ini adalah Dengan memberikan pemahaman dan pelatihan kepada tukang kayu di Kelurahan Woloan Dua, Kecamatan Tomohon Barat, Kota Tomohon. dapat memahami tentang teknik perancangan gambar rumah panggung.

Pelatihan ini mempunyai beberapa tujuan antara lain:

1. Sebagai upaya memberi ketrampilan yang lebih modern khususnya teknik perancangan gambar rumah panggung; dan

2. Meningkatkan pengetahuan tentang teknik perancangan gambar rumah panggung.

\section{TINJAUAN PUSTAKA}

Prinsip Rumah Panggung (home stage) adalah mengangkat lantai rumah diatas tiang-tiang setinggi 60-300 cm. Rumah Panggung atau rumah kolong memiliki penyelesaian dari persoalan perumahan dengan berkualitas tinggi yaitu:

1. Sehat karena tidak terkena kelembaban tanah secara langsung dan binatangbinatang yang mengganggu karena letak lantai berada diatas jarak tertentu dengan tanah;

2. Dapat melindungi bangunan dari kelembaban tropika yang amat ganas yang mudah membusukan bangunan, terutama daerah rawan banjir; dan

3. Tahan gempa. Agar suatu bangunan dapat menahan gempa, gaya inersia gempa harus dapat disalurkan dari tiaptiap elemen struktur kepada struktur utama gaya honisontal yang kemudian 
memindahkan gaya-gaya ini ke pondasi dan ke tanah. Adalah sangat penting bahwa struktur utama penahan gaya horizontal itu bersifat kenyal. Karena, jika kekuatan elastis dilampaui, keruntuhan getas yang tiba-tiba tidak akan terjadi, tetapi pada beberapa tempat tertentu terjadi Ieleh terlebih dulu. Suatu contoh misalnya deformasi paku pada batang kayu terjadi sebelum keruntuhan akibat momen lentur pada batangnya. Cara dimana gaya-gaya tersebut dialirkan biasanya disebut jalur lintasan gaya. Tiap-tiap bangunan harus mempunyai jalur lintasan gaya yang cukup untuk dapat menahan gaya gempa horisontal seperti pada Gambar 1.
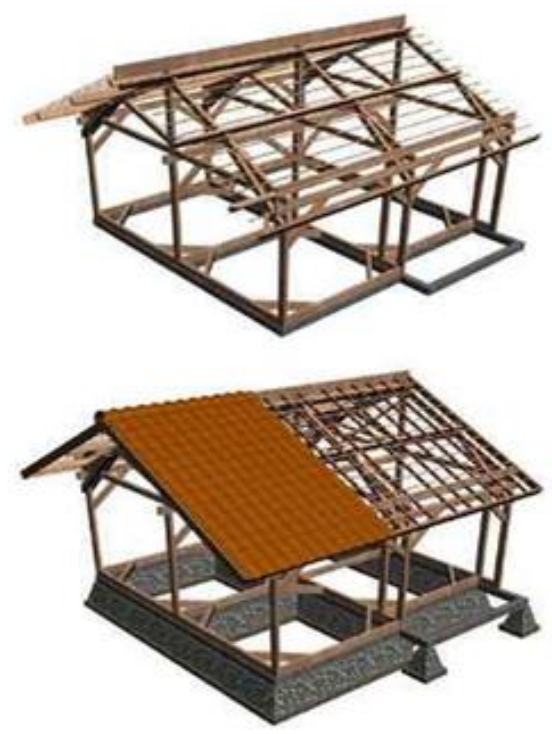

Gambar 1. Contoh perancangan gambar rumah panggung tahan gempa.

Perancangan Rumah Panggung dengan menggunakan bahan-bahan bangunan dari alam yang sangat memprioritaskan kualitas lingkungan, vitalitas ekonomi dan keuntungan sosial yang dapat digunakan dalam jangka waktu panjang dan bermanfaat untuk masa yang akan datang, dimana penghuni dapat hidup dengan nyaman, tanpa merugikan kehidupan manusia yang akan datang.
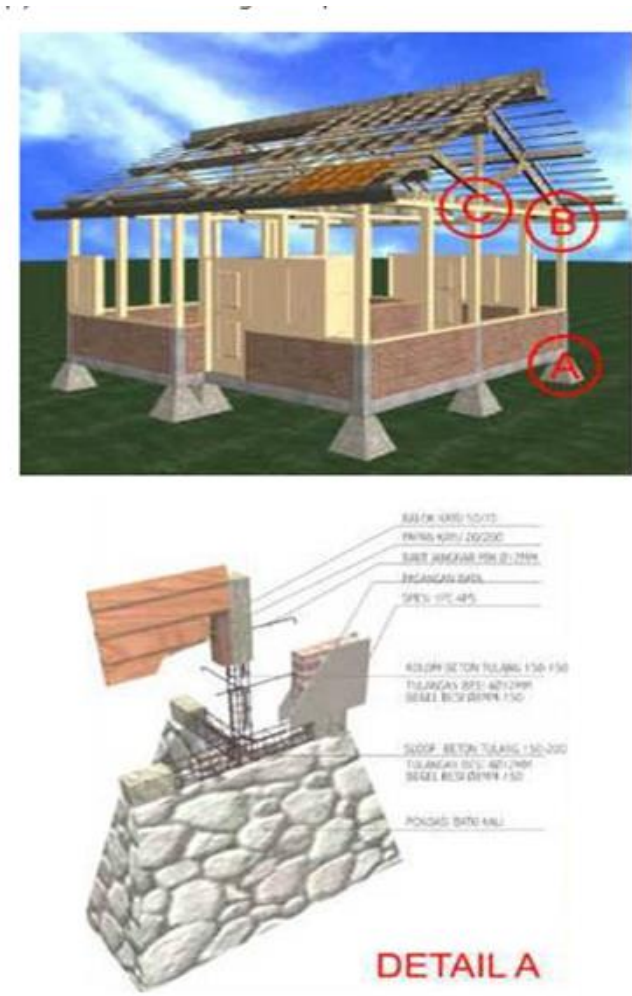

Gambar 1 (lanjutan). Contoh perancangan gambar rumah panggung tahan gempa.

Beberapa aspek dalam merencanakan dan merancang serta merenovasi rumah panggung agar optimal sebaiknya perlu mempertimbangkan dan mempersiapkan terlebih dahulu mengenai:

1. Biaya dan konsep desain. Pada tahap ini, diperlukan estimasi biaya yang ada dan prioritas menentukan bagian rumah mana saja yang akan perbaiki, perlukah 
menggunakan kembali material yang lama atau tidak. Bila ingin menggunakan material lama tentu harus dibongkar secara hati-hati agar tidak rusak. Sistem pembayaran kepada tukang juga akan mempengaruhi efisiensi biaya, pada umumnya sistem pembayaran umumnya terbagi dua, yaitu borongan dan harian. Bila sudah pasti apa yang akan direnovasi dan sudah mengetahui konsep renovasi secara matang, maka lebih baik menggunakan sistem borongan. Sebaliknya, bila konsep renovasi belum jelas sebaiknya menggunakan sistem pembayaran tukang secara harian. Pada prinsipnya apabila dana yang tersedia terbatas kreatifitas dalam menyiasati disain akan menentukan optimalisasi suatu produk rumah panggung tersebut. Sedangkan menentukan konsep desain sebelum merencanakan dan merancang ataupun merenovasi berguna agar hasilnya sesuai dengan yang diinginkan, pada konsep disain agar optimal perlu dipertimbangkan faktor berikut ini:

a. Persyaratan ruang, meliputi:

- Penghawaan;

- Pencahayaan;

- Akustik.

b. Organisasi ruang yang meliputi:

- Macam ruang;

- Besaran ruang;

- Hubungan ruang;

- Pengelompokan ruang;

- Sirkulasi aktivitas. c. Struktur dan konstruksi, meliputi:

- Sub struktur (struktur pondasi);

- Midle struktur (struktur dinding);

- Up struktur (struktur atap).

d. Utilitas, meliputi:

- Sanitasi;

- Elektrikal.

2. Keahlian pelaksana atau tukang. Hasil akhir kualitas bangunan rumah panggung sangat ditentukan oleh keahlian dari tukang atau pelaksananya. Walaupun biaya dan konsep disain sudah dipersiapkan secara matang ,namun apabila kompetensi pelaksana atau tukang tidak maksimal maka kualitas hasil akhir dari bangunan tersebut juga tidak akan optimal.

3. Kualitas dan material bangunan. Keterbatasan dana dapat diatasi dengan penggunaan barang-barang berkualitas sedang atau barang bekas. Pemilihan dengan cermat, dapat menemukan barang bekas tapi berkualitas baik. Penggunaan barang-barang berkualitas sedang, misalnya untuk keramik lantai, kayu-kayu, kusen, atau cat interior. Keramik yang dipasang dengan teknik yang baik dapat menghasilkan lantai yang indah walaupun menggunakan keramik kualitas sedang. Sedangkan bagian-bagian yang wajib menggunakan barang-barang dengan kualitas baik adalah pada bagianfondasi rumah, pipa 
air yang ditanam, struktur bangunan, rangka atap.

4. Urutan prioritas pekerjaan. Pekerjaan yang paling urgent sebaiknya diutamakan agar waktu yang digunakan lebih cepat dan dapat menghemat biaya. Tahapan rencana pekerjaan secara makro agar target kegiatan dapat terpenuhi secara optimal dapat diurutkan sebagai berikut:

a. Tahap persiapanPada tahapan ini adalah mempersiapkan segala sesuatu dalam kegiatan membangun, seperti: kebutuhan kebutuhan perijinan, kesiapan lahan, kebutuhan tenaga tukang, kebutuhan pengamanan, kebutuhan sarana pendukung aktifitas membangun seperti air, listrik, dan gudang penyimpanan material.

b. Tahap sub struktur. Pada tahap ini merupakan pengerjaan pondasi, untuk meminimalisir kesalahan pekerjaan pada tahap ini perlu sinkronisasi keadaan di lapangan dengan gambar disain yang sudah ditentukan.

c. Tahap midle struktur. Pada tahap midle struktur adalah tahap pekerjaan dinding serta bukaanbukaannya, untuk mengantisipasi kesalahan yang timbul. Pada tahapan ini sebaiknya perlu sinkronisasi kondisi di lapangan dengan gambar disain yang ada, misalnya berapa tinggi dinding, di mana saja letak kusen pintu dan jendelanya dan lain-lain.

d. Tahap up struktur. Tahapan ini merupakan tahap pengerjaan struktur konstruksi atap dan penutupnya, selain gambar disain yang dijadikan sebagai pedoman pengerjaan, pemilihan sistem struktur dan bahan juga akan mempengaruhi optimal tidaknya pada tahapan ini.

e. Tahap finishing. Tahap finishing merupakan tahapan akhir dari proses pengerjaan bangunan. Pada tahap ini, perlu pertimbangan dan pemikiran yang lebih terencana mengenai material finishing yang akan digunakan, karena pemilihan material finishing akan berpengaruh pada keawetan bangunan, waktu dan biaya pekerjaan bangunan tersebut. Harga material finishing bangunan yang relatif mahal di pasaran biasanya bersifat awet dan mudah dalam pengolahannya, sebaliknya jika material tersebut harganya murah biasanya tidak awet dan susah dalam pengolahannya, sehingga diperlukan survey dan kecermatan dalam pemilihan material finishing.

5. Waktu yang tepat. Waktu pelaksanaan pembangunan sebaiknya direncanakan secara matang. Tidak semua tahapan pekerjaan harus dilakukan pada saat musim kemarau dan tidak juga pada musim hujan. Pada musim kemarau 
sebaiknya tahapan pekerjaan sub struktur, midle struktur dan up struktur sedapat mungkin dapat terselesaikan. Sehingga pada saat musim hujan dapat mendeteksi pengaruh air hujan terhadap bangunan, misalnya kebocoran atap, kebocoran dinding, tersumbatnya saluran pembuangan dan lain-lain.

\section{METODE PELAKSANAAN}

\section{Kegiatan Pelatihan}

Metode kegiatan pelatihan adalah mengundang pemerintah setempat, tokoh-tokoh masyarakat, tukang kayu di Kelurahan Woloan Dua, Kecamatan Tomohon Barat, Kota Tomohon dengan memberikan naskah materi dan dipresentasikan lewat LCD.

Adapun prosedur pelatihan adalah persiapan, pembukaan, pemaparan materi, Tanya jawab, latihan-latihan, evaluasi, dan penutupan, yang detailnya sebagai berikut:

1. Persiapan: menyiapkan tempat pelatihan, naskah materi, LCD, dan mengundang Pemerintah Kelurahan, Pemerintah Kecamatan, dan tokoh-tokoh masyarakat Kelurahan Woloan Dua;

2. Pembukaan: dibuka oleh Camat Tomohon Barat;

3. Pemaparan Materi: yang akan memaparkan materi adalah pelatih dengan menggunakan metode ceramah;

4. Tanya Jawab: Peserta pelatihan diberikan kesempatan bertanya kepada pelatih dan pelatih menjawab pertanyaan peserta;
5. Latihan-latihan: memberikan pelatihan teknik perancangan gambar rumah panggung;

6. Evaluasi: memberikan soal tes kepada peserta tentang pemahaman mengenai materi yang sudah diberikan; dan

7. Penutupan: rencana penutupan acara kegiatan pelatihan akan ditutup oleh Lurah Woloan Dua.

\section{Peserta}

Peserta adalah seluruh tukang kayu di Kelurahan Woloan Dua, Kecamatan Tomohon Barat, Kota Tomohon.

\section{Pelaksanaan Pelatihan}

Pelaksanaan kegiatan pelatihan berlangsung 2 hari dengan waktu efektif selama 16 jam, dan monitoring pelaksanaan pekerjaan bangunan Rumah Panggung yang sedang dan sementara dikerjakan tukang selama 3 bulan.

\section{Tempat dan Waktu Pelaksanaan}

Tempat pelaksanaan kegiatan pelatihan di Gedung Kantor Kelurahan Woloan Dua, Kecamatan Tomohon Barat, Kota Tomohon, dan telah dilaksanakan pada Bulan September 2018 sampai Bulan November 2018.

\section{HASIL DAN PEMBAHASAN}

\section{Hasil yang Dicapai}

Hasil pelaksanaan kegiatan secara garis besar dapat dijelaskan sebagai berikut: 
1. Langkah awal kegiatan PKM berupa penyampaian usulan pelatihan teknik perancangan gambar rumah panggung kepada Bapak Lurah Woloan Dua, diterima dengan baik. Dengan demikian masyarakat di lokasi pengabdian siap menerima tim PKM Unima untuk melaksanakan kegiatan pelatihan di wilayahnya;

2. Jadwal pelatihan dilaksanakan selama 2 (dua) hari. Pelaksanaan pelatihan pertama, yaitu hari Selasa, tanggal 25 September 2018, sedangkan pelaksanaan pelatihan kedua, yaitu hari Selasa, tanggal 6 November 2018;

3. Pembahasan materi pelatihan oleh tim pengabdi menyepakati bahwa pada hari pertama dilakukan pelatihan dengan metode ceramah dan menggunakan media berupa makalah. Ada 2 (Dua) materi yang disampaikan kepada peserta pelatihan yaitu: Prinsip Perencnaan Rumah Panggung, dan Aspek Perencanaan dan Perancangn Rumah Panggung. Penyampaian materi dilakukan oleh tim PKM Unima dibantu Lurah dan Pegawai Kelurahan Woloan Dua. Pada hari kedua dilakukan pelatihan dengan metode demonstrasi dengan media berupa cara menggambar dengan cepat memakai program Autocat dan dilanjutkan oleh peserta pelatihan di bawah petunjuk narasumber;

4. Pelaksanaan pelatihan terhadap masyarakat di lokasi pengabdian, yaitu: a. Pelaksanaan pelatihan pertama pada hari Selasa, tanggal 25 September 2018 di Kantor Kelurahan dihadiri oleh 15 orang peserta. Hal ini menunjukkan antusiasme masyarakat di lokasi pengabdian cukup besar dengan program pengabdian dari tim PKM UNIMA;

b. Materi pelatihan semuanya dapat disampaikan oleh tim PKM Unima, meskipun tidak disampaikan secara detil;

c. Kemampuan peserta pelatihan dalam penguasaan materi cukup baik, hal ini dapat dilihat dari antusiasme peserta dalam sesi diskusi dan tanya jawab. Beberapa pertanyaan yang diajukan oleh peserta, antara lain: (1) bagaimana cara mendesain rumah panggung yang ekonomis, (2) bagaimana cara menghitung volume pemakaian material, (3) bagaimana teknik menghitung RAB rumah panggung seperti pada gambar 2;

d. Pelaksanaan pelatihan pertama berjalan lancar sesuai rencana, sehingga diharapkan kegiatan pengabdian dapat meningkatkan pengetahuan dan kesadaran masyarakat tentang teknik perancangan gambar rumah panggung;

e. Pelaksanaan pelatihan kedua pada hari Selasa, tanggal 6 November 
2018. Kegiatan tersebut juga dihadiri 15 orang peserta.

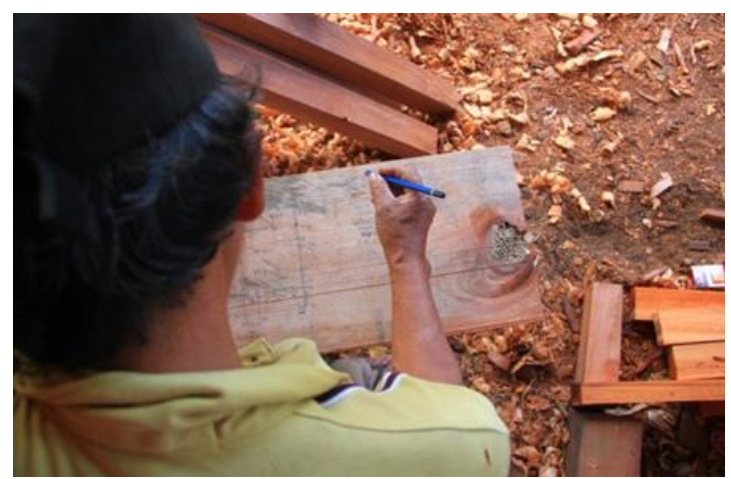

Gambar 2. Peserta menggambar sketsa rumah panggung di atas papan.

f. Monitoring kegiatan oleh tim pengabdi dilakukan pada hari Sabtu, tanggal 17 November 2018 dengan mendatangi tempat pembuatan Ruamah Panggung Woloan; dan

g. Pelaporan kegiatan pengabdian dilakukan secara tertulis kepada LPPM Unima. Sebelum pengumpulan laporan akhir PKM dilakukan kegiatan seminar akhir untuk mendapatkan beberapa masukan perbaikan laporan oleh teman sejawat.

\section{Pembahasan}

Hasil pelaksanaan kegiatan PKM secara garis besar dapat dilihat dari penilaian beberapa komponen sebagai berikut:

1. Keberhasilan target jumlah peserta pelatihan, dapat dinilai sangat baik, mengingat target jumlah peserta pelatihan sebanyak 15 orang, sementara itu dalam pelaksanaan kegiatan pelatihan baik hari pertama maupun kedua yang dapat hadir juga sebanyak 15 orang (100\%);

2. Ketercapaian tujuan pelatihan, keterbatasan waktu yang disediakan mengakibatkan tidak semua materi dapat disampaikan secara detil. Banyak di antara materi yang hanya disampaikan secara garis besar, sehingga sangat memungkinkan peserta dengan latar belakang pendidikan berbeda masih kurang paham dengan materi yang diberikan oleh tim pengabdi. Kegiatan tersebut dilanjutkan dengan demonstrasi cara menggambar dengan cepat memakai program Autocat di lokasi pengabdian pada waktu lain. Dilihat dari antusiasme peserta dalam forum diskusi dan tanya jawab serta pelaksanaan demonstrasi maka ketercapaian tujuan pelatihan dapat dinilai baik (80\%), hal ini dikarenakan adanya peningkatan pengetahuan dari peserta terhadap cara teknik perancangan gambar rumah panggung;

3. Ketercapaian target materi yang telah direncanakan, dapat dinilai baik (80\%) karena materi pelatihan telah dapat disampaikan secara keseluruhan meskipun tidak secara detil akibat keterbatasan waktu.

\section{KESIMPULAN}

Berdasarkan hasil ketercapaian pelatihan, maka dapat ditarik beberapa kesimpulan sebagai berikut ini: 
1. Kegiatan pengabdian dapat meningkatkan pengetahuan masyarakat tentang teknik perancangan gambar rumah panggung; dan

2. Untuk lebih meningkatkan pengetahuan dan ketrampilan masyarakat dilakukan penerapan cara menggambar dengan cepat memakai program Autocat.

\section{UCAPAN TERIMA KASIH}

1. Kepada Prof. Dr. Julyeta P.A. Runtuwene, M.S, dea sebagai Rektor Universitas Negeri Manado yang telah mendanai PKM ini.

2. Kepada Prof. Dr. Revolson A. Mege, M.S., sebagai Kepala LPPM UNIMA yang telah memberikan motivasi dan rekomendasi sehingga PKM ini dapat dilaksanakan.

\section{KEPUSTAKAAN}

A.W. Charleson, M.E., MNZIE. 1972 "Konstruksi Rumah Tahan Gempa Di Indonesia" Erlangga, Jakarta. Indonesia.

Teddy Boen, Ir., 2005 "Manual Bangunan Tahan Gempa". Erlangga, Jakarta. Indonesia.

Verhoef P.N.W.,1985, Geologi untuk Teknik Sipil, Edisi ke 3, Erlangga, Jakarta. Indonesia.

Suryolelono, K. B., 2004, Perancangan Fondasi, Nafiri, Yogyakarta, Indonesia.

Schroeder, W.L., 1975 "Soil in Construction", John Wiley \& Sons, Inc, New York. 
Jurnal ABDIMAS, Vol. 11, No. 3, Desember 2018

ISSN: 1979-0953 | e-ISSN: 2598-6066 